\title{
The Eocene flora of Tatabánya "marl-mine" (N Hungary)
}

\author{
Boglárka Erdei ${ }^{1}$ (i) $\cdot$ Volker Wilde $^{2}$
}

Received: 15 January 2019 / Revised: 4 March 2019 / Accepted: 9 September 2019 / Published online: 6 February 2020

(C) The Author(s) 2020

\begin{abstract}
The middle Eocene (Lutetian) fossil plant assemblage from Tatabánya (N Hungary) comprises plant remains preserved mostly as impressions. Remains of angiosperms are represented by Lauraceae (Laurophyllum div. sp., Daphnogene Unger), Rhamnaceae (Ziziphus Miller), Malvaceae s.l. (Byttneriopsis Z.Kvaček et Wilde), Leguminosae, and Palmae, and the occurrence of other families, i.e., Dioscoreaceae, Myrtaceae, Fagaceae, Anacardiaceae, Berberidaceae, Juglandaceae, and Theaceae, is uncertain. The scarcity of gymnosperms is a character similar to the coeval floras of Csordakút (N Hungary) and Girbou in Romania. The presence of Ziziphus ziziphoides (Unger) Weyland, high number of linear shaped leaves with entire margin and coriaceous texture (Lauraceae vel Fagaceae), and small-leaved Leguminosae suggests a "subhumid" character of the vegetation, which is recognisable also in early Palaeogene floras of eastern Central and Southeastern Europe, e.g., the Tard Clay floras in Hungary and floras of Serbia/Macedonia. In contrast, the Eocene floras from Central/Western Europe are indicative of a generally non-xerophytic character, e.g., Staré Sedlo in Bohemia, Messel, Geiseltal, and the Weisselster Basin floras in Germany. A frost-free climate with high mean annual temperatures similar to that estimated for coeval European floras may also be inferred for the Tatabánya flora.
\end{abstract}

Keywords Palaeobotany $\cdot$ Eocene $\cdot$ Lutetian $\cdot$ Plant macrofossils $\cdot$ Hungary

\section{Introduction}

Plant fossil record from the Eocene of Hungary

Reports on Eocene plant fossils from Hungary are scarce and often deal with few or even single specimens, which have exclusively been recorded from the Transdanubian region. From the middle Eocene of Budapest (Martinovics Hill), a palm fruit, Actinorhytis eocaenica (Tuzson) Rásky (Juglandites eocaenica Tuzson in Tuzson 1913), and a dicotyledonous flower, Monotes oeningiensis (Heer) Weyland, were recorded by Rásky (1956a). Furthermore, fruits of the "mangrove palm” Nypa Wurmb ("Nipa burtinii (Brongniart)

Boglárka Erdei

erdei.boglarka@nhmus.hu

Volker Wilde

Volker.Wilde@senckenberg.de

1 Botanical Department, Hungarian Natural History Museum, Könyves K. krt. 40., Budapest 1087, Hungary

2 Sektion Paläobotanik, Senckenberg Forschungsinstitut und Naturmuseum, Senckenberganlage 25, 60325 Frankfurt am Main, Germany
Ettingshausen") were reported (Schafarzik and Vendl 1929; Andreánszky 1954; Pálfalvy 1965).

From west of Budapest, Nypa (Nipadites burtini Brongniart) was documented from Dudar in the Bakony Mts. (Rásky 1948), a fruit from Tokod was described as Xylopiaecarpum eocaenicum Rásky (Annonaceae) (Rásky 1956b), and a fragment of a leaf from Felsőgalla (Rásky 1956b) was determined as Apocynophyllum plumieroides Staub. Furthermore, ferns were described from the same area, including a fragment of Acrostichum lanzaeanum (Visiani) Reid et Chandler (Pálfalvy 1966a) from the Solymár Basin, and a fragment of a frond from Balinka, which was identified as Stenochlaena palustris (Burman) Beddome by Kovács (1957a). Another middle Eocene flora comprising more taxa was recorded from Lábatlan in the Dorog Basin, N Hungary. Kovács (1961) published a huge list with taxa like Blechnum Linnaeus, Buettneria apiculata Kovács, Castanopsis furcinervis (Rossmässler) Kräusel and Weyland, Cedrela P.Browne, Cedrelospermum Saporta, Cinnamomum polymorphum Heer, Dryophyllum Debey, Eucalyptus L'Héritier de Brutelle, Leguminosae, Magnolia Linnaeus, Myrica Linnaeus, Palmae, Pterocarya Kunth, Quercus Linnaeus, and Sequoia Endlicher from the locality. However, only a limited number of taxa from the assemblage were figured by Kovács. 
The flora of Lábatlan was revisited by Z. Kvaček during a visit to Budapest in 1989. Z. Kvaček (in Knobloch et al. 1996) mentioned the similarity of a predominant leaf type ("Eucalyptus" transdanubica Kovács) to Apocynophyllum helveticum Heer and proved the occurrence of Juglandaceae by cuticular analysis.

From the Lutetian of Csordakút (Gerecse Mts), a fossil flora was published by Erdei and Rákosi (2009). Remains of gymnosperms are absent from the fossil plant assemblage. Angiosperms were identified as Daphnogene sp., cf. Eotrigonobalanus furcinervis (Rossmässler) Walther et Z. Kvaček, Cedrelospermum div. sp., Myrica sp., Comptonia div. sp., Leguminosae (leaves and fruit), ?Ziziphus ziziphoides (Unger) Weyland, Sloanea nimrodii (Ettingshausen) Z. Kvaček et Hably, Sloanea sp. (fruit), Smilax div. sp.

Kedves studied the palynoflora of numerous Eocene sections from the region of Halimba (Bakony Mountains, Kedves 1961), the Dorog Basin (Kedves 1960), Solymár (Pilis Mountains, Kedves 1966a), and the Tatabánya Basin (Kedves 1962a) and recorded Palmae, Castanea Miller, Quercus, Myricaceae, Fagaceae, Taxodiaceae-Cupressaceae, Nyssaceae, Pinus Linnaeus., Sterculiaceae, Ericaceae, Aquifoliaceae, Engelhardia Leschenault de la Tour ex Blume, Anacardiaceae, Cycadales, etc. (Kedves 1963a; Kedves and Kolosváry 1966).

Fossil plants from Tatabánya

The first report on plant fossils from Tatabánya (Hosszúhajtai Valley in Pálfalvy 1966b) was published by Andreánszky (1951). The fossils were recovered from the Operculina-bearing clay marl and the overlying sandstones. According to Pálfalvy (1966b), the plant assemblage from the sandstones is richer than that from the clay marl. From the clay marl, Andreánszky (1951) especially mentioned Leguminosae (both fruits and leaves, including Mimosocarpum Andreánszky). Later Pálfalvy (1966b) added Cinnamomophyllum Kräusel et Weyland (Lauraceae), Myrica (Myricaceae), Palmae, Quercus (Fagaceae), Sapotaceae, and Engelhardia to the list. According to palynological studies (Kedves 1962a, 1963b, 1966b), spores of Osmundaceae, Polypodiaceae, and Schizaeaceae predominate in the clay marl, but pollen assigned to Palmae (e.g., Calamus Linnaeus), Ericaceae, Fagaceae, Juglandaceae, Meliaceae, Myricaceae, Sapotaceae, and Sterculiaceae were also mentioned. Based on the thin-shelled molluscs of the clay marl and the predominance of pteridophyte spores, Pálfalvy (1966b) suggested a calm nearshore depositional environment.

From the overlying sandstones, Pálfalvy (1966b) mentioned Annonaceae, Aquifoliaceae, Fagaceae, Lauraceae, Magnoliaceae, Myricaceae, Myrtaceae, Palmae, Sapotaceae, Sterculiaceae, Zizyphus zizyphoides, and some ferns including a new species, Stenochlaena transdanubica Pálfalvy, all from the Rozlozsnik collection, which is deposited in the former Hungarian Geological Survey, now Mining and Geological
Survey of Hungary (MBFSZ, Budapest). Kovács (1957b) published some additional plant remains from the brown coal deposits of Tatabánya (shafts IX and XI) which are underlying the clay marls and assigned them to the genus Dracontomelon Blume (Dracontomelon minimum Reid et Chandler) but Manchester (1994) reassigned both the London Clay and Tatabanya occurrences to the extinct anacardiaceous genus Pentoperculum Manchester.

According to Kovács (1968), a collection made by Skoflek in 1963-1964 at the so-called Tatabánya I and II localities and also stored in the MBFSZ includes taxa like Actinodaphne Nees, Anacardiaceae, Apocynophyllum Heer, Buettneria apiculata Kovács, Castanopsis furcinervis (Rossmässler) Kräusel et Weyland, Cedrela, Cupania Linnaeus, Diospyros Linnaeus, Dodonaea Miller, Dryophyllum, Grewiopsis De Wildeman et T.Durand, Illicium Linnaeus, Lauraceae, Leguminosae, Lithocarpus Blume, Magnolia, MagnoliaceaeAnnonaceae, Michelia Linnaeus, Myrica, Notelaea Ventenat, Palmae, Persea Miller, Plumeria Linnaeus, Quercus, Sapindus Linnaeus, Stenochlaena J.Smith, Strychnos Linnaeus, and Ziziphus ziziphoides. Unfortunately, nothing was figured from the collection by the author except for only three types of leaves which were assigned to Laurus assimilis Saporta, Magnoliaceae, and Sapindus sp., respectively.

Later, Hably (1985) published some taxa from TatabányaMárgabánya ("marl-mine") and noted that this locality is not identical with those mentioned above, i.e., Castanopsis elisabethae Kolakovsky, Engelhardia orsbergensis (Wessel et Weber) Jähnichen, Mai et Walther, Nyssa sp., Ocotea obtusifolia (Berry) La Motte, Paliurus cf. tiliaefolius (Unger) Bůžek, Sabal major (Unger) Heer, and Zizyphus zizyphoides.

The present paper focuses on specimens which were collected by Skoflek in Tatabánya in the 1980s. A reinvestigation and revision of the collections mentioned above is beyond the scope of this study.

\section{Geology, stratigraphy, and age of the locality}

In Hungary, Eocene rocks discordantly overlie older (Mesozoic or Paleozoic) strata (Kecskeméti 1998). The total thickness of middle and upper Eocene sediments does not exceed 500 $700 \mathrm{~m}$. The rocks comprising the flora of Tatabánya "marl-mine" (Fig. 1) belong to the Csolnok Claymarl Formation and are called as well "Operculine marl" or "Nummulite marl" because of the sometimes high or even rock-forming quantities of foraminifera (Kecskeméti 1998). Based on the occurrence of Nummulites subplanatus Hantken and $N$. variolarius Lamarck, which are indicating the first marine sediments of the Eocene transgression, Kecskeméti (in Hably 1985) assigned the fossiliferous sediments to the Lutetian (middle Eocene). On the other hand, the "Operculine marl" (cited as belonging to the Dorog Formation 
Fig. 1 Geographic position of the Tatabánya "marl-mine" locality and a simplified geological map for the area of Tatabánya (modified after Selmeczi in Hably et al. 2015)

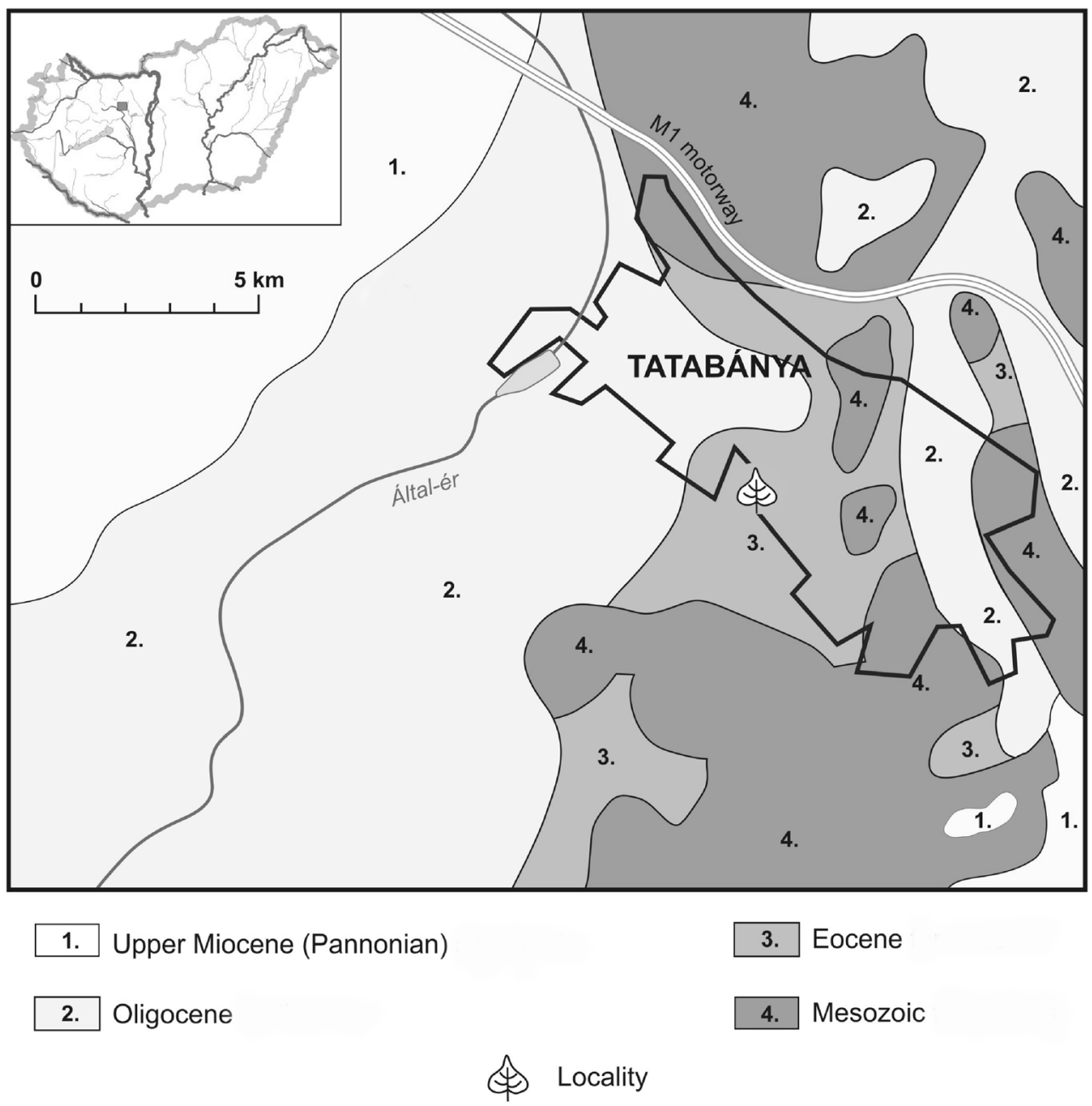

Geographic position of the Tatabánya "marl-mine" locality and a simplified geological map for the area of Tatabánya (modified after Selmeczi in Hably et al. 2015).

in Báldi-Beke 1984) was dated as NP16 nannoplankton zone (upper Lutetian) based on the occurrence of Reticulofenestra placomorpha (Kamptner) Stradner in Stradner et Edwards, Pemma papillatum Martini, and Sphenolithus furcatolithoides Locker (Báldi-Beke 1984).

\section{Material and methods}

Fossils included in this study were collected by István Skoflek in the 1980s from the Tatabánya "marl-mine" locality (Fig. 1). The collection at our disposal consists of nearly 400 specimens that are housed in the Kuny Domokos Museum, Tata (N Hungary) (abbreviation “TB"). Fossils are almost exclusively leaves; fruits are only represented by a couple of poorly preserved specimens.

Fossils are preserved in yellowish, often reddish carbonaceous sandy clay. Leaves are mostly preserved as impressions and rarely as blackish compressions; however, our attempts to prepare cuticles mostly failed. Leaves are often fragmented, and entire specimens with apex, base, and leaf margin preserved are rare. The margin of the leaves is often damaged. This suggests transport and/or decay of the plant material before final burial; however, incompleteness of leaves is often caused by the irregular cleavage of the rock.

Rarely, leaves are characterised by a texture more resistant to decay and retained cuticles showing epidermal details. Cuticles were isolated following the conventional method including rock-digestion by $\mathrm{HCl} / \mathrm{HF}$, oxidation with $\mathrm{HNO}_{3}$ (instead of Schulze's solution), and leaching by an aqueous solution of $\mathrm{KOH}$.

The cuticles were studied with transmitted light, interference contrast, and epifluorescence microscopy (Nikon Eclipse E600 type microscope equipped with a SPOT digital camera). Digital photos were processed with the software "Image-Pro Plus Ver. 4." 


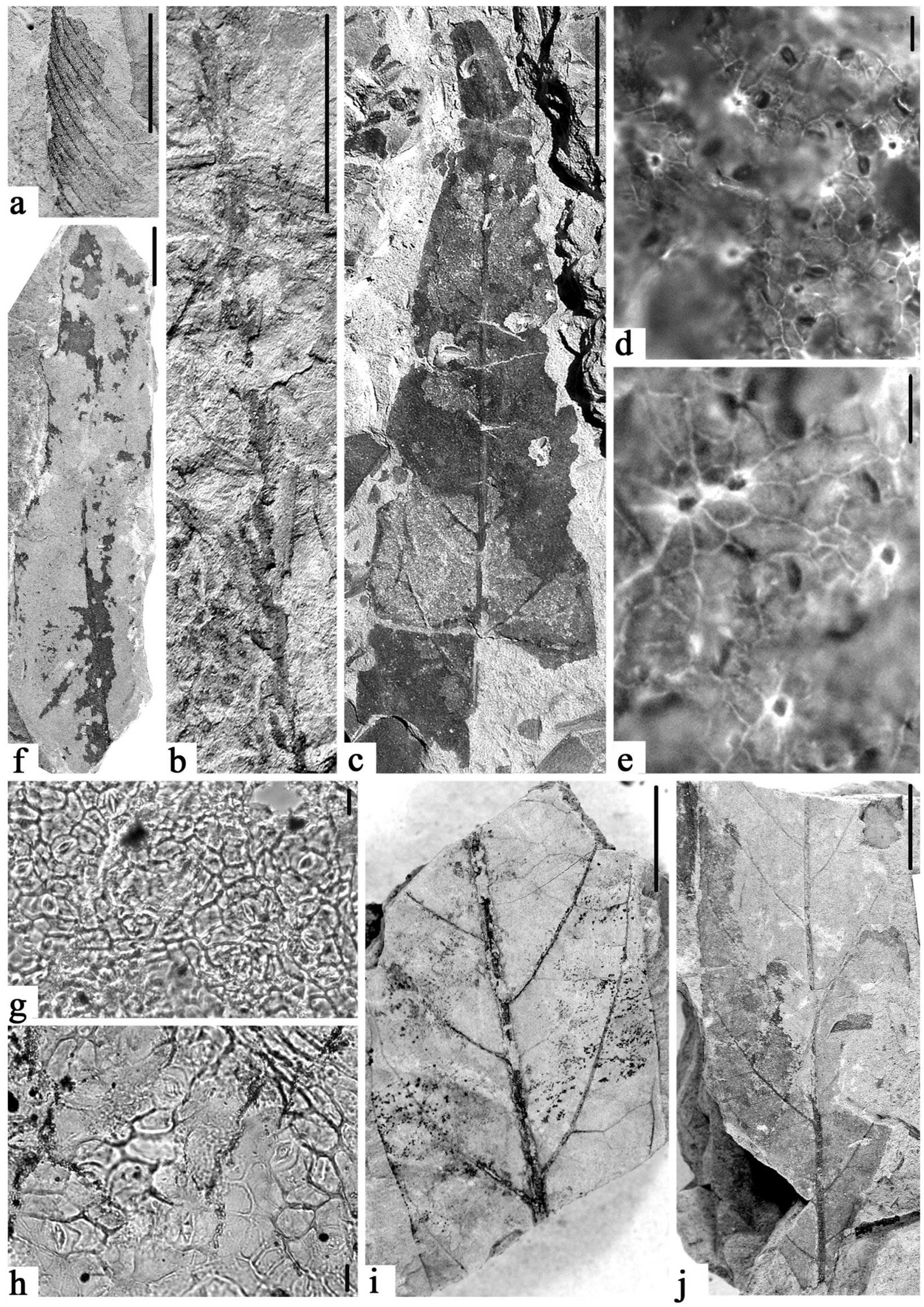


Fig. 2 a Pteridophyta, fragment of a pinna or pinnule; TB.83.587.1; scale bar $1 \mathrm{~cm}$. b ?Cupressaceae s.1., twig fragment; T.B.83.484.1, scale bar 1 cm. c-e Laurophyllum ?kinkelinii (Engelhardt) Kvaček; TB.83.293.1; c leaf fragment, scale bar $1 \mathrm{~cm}$, d abaxial cuticle showing stomata and trichome bases, fm, scale bar $30 \mu \mathrm{m}$. e Abaxial cuticle showing stomata and trichome bases, fm, scale bar $30 \mu \mathrm{m}$. f-h cf. Ocotea hradekensis (Kvaček et Bůžek) Kvaček; TB.83.385.1; f fragmented leaf, scale bar $1 \mathrm{~cm}$. g Abaxial cuticle showing stomata, $1 \mathrm{~m}$, scale bar $30 \mu \mathrm{m}$. h Abaxial cuticle showing stomata, $1 \mathrm{~m}$, scale bar $30 \mu \mathrm{m}$. i Laurophyllum sp., leaf; TB.83.369.1.; scale bar $1 \mathrm{~cm}$. j Laurophyllum sp., leaf; TB.83.493.1.; scale bar $1 \mathrm{~cm}$

\section{Results}

Pteridophyta

Figure $2 \mathrm{a}$

\author{
Material: TB.83.587.1 \\ Description: A tiny fragment from the marginal part of a \\ pinna or pinnule.
}

Gymnosperms

?Cupressaceae s.1.

Figure $2 b$

\section{Material: T.B.83.484.1}

Description: The only putative record of gymnosperms is a poorly preserved twig fragment with ?helically arranged scale-like leaves; however, cuticle was not retained.

\section{Angiospermae \\ Lauraceae \\ Laurophyllum Göppert \\ Laurophyllum ?kinkelinii (Engelhardt) Kvaček}

Figure 2c-e

Material: TB.83.293.1; TB.83.435.1; TB.83.479.1

Description (TB.83.293.1): Fragment from the upper half of leaf, up to $7 \mathrm{~cm}$ long and $2.2 \mathrm{~cm}$ wide, entire margined. Shape of lamina narrow, ?elliptic. Apex attenuate. Venation camptodromous, midrib moderate. Six pairs of secondary veins arise at angles of $45-50^{\circ}$. Tertiary venation not visible.

Adaxial cuticle not preserved, arrangement of epidermal cells on abaxial cuticle barely recognisable (therefore epifluorescence was applied to reveal more details).

Anticlinal cell walls slightly thickened, curved, epidermal cells isodiametric, 13-28 $\mu \mathrm{m}$ in diameter. Randomly arranged stomata and single-celled trichome bases occur in high number. Elongated cells and trichomes (trichome bases) clearly indicate the course of the veins. Stomata paracytic, 15-20 $\mu \mathrm{m}$ wide and 13-18 $\mu \mathrm{m}$ long, stomatal pore 4-5 $\mu \mathrm{m}$ long, stomatal ledges not thickened. Trichome bases with 6-9 surrounding cells, basal cell thickened with bright fluorescence, trichomes not preserved.

Discussion: The above description fits best to leaves of Lauraceae and the fossil leaf is therefore assigned to the form genus Laurophyllum. The epidermal details, namely, the structure of epidermal cells and stomata, the hardly discernible outlines of ordinary cells and stomata, and the high number of trichome bases are most comparable to L. kinkelinii as described from the early Oligocene flora of Flörsheim (Kvaček 2004). However, in the lack of more macromorphological details, the assignment of the leaf fragment to the species is uncertain.

Considering Laurophyllum species reported so far from this area (equivalent to the later central Paratethys), L. acutimontanum Mai and L. markvarticense Kvaček show some similarities in having elongate leaves and apex. L. acutimontanum has similar trichome bases but these occur only sparsely. The species differs also in having more or less papillate cells encircling the stomata and slightly overlapping the stomatal pore (Mai 1963; Kvaček 1971). L. markvarticense has very scanty trichome bases (Kvaček 1971) in contrast to the present leaf which is characterised by a high number of them.

The epidermal characters of L. pseudovillense Kvaček show the greatest similarity, i.e., quite small paracytic stomata and trichome bases of more or less similar structure (Kvaček 1971). However, such a density of trichome bases has neither been reported from the type material of L. pseudovillense (Kvaček 1971) nor in later reports of the species (KovarEder et al. 1998; Meller et al. 1999). Furthermore, a rim around the basal cell of the trichomes is not so expressed in our material. A somewhat similar epidermal structure may be observed in Laurophyllum sp. leaves from the Oligocene flora of Csolnok, Hungary (Erdei and Wilde 2004), although stomata are slightly smaller for the present material than those of the Csolnok leaves (length 15-20 $\mu \mathrm{m}$, width 18-25 $\mu \mathrm{m}$ ). The leaves from Csolnok are less elongate and have an acute apex contrasting with the Laurophyllum leaves from Tatabánya having long attenuate apex and narrow lamina. In addition, unlike on those from Csolnok, a large number of trichome bases and no papillate structures have been observed on the cuticle of the leaf from Tatabánya. It should be noted, however, that the density of trichomes may be the result of different ecological constraints (e.g., sun/shade leaves, lower humidity; see Johnson 1975).

Kvaček (2004) compared the fossil leaves of L. kinkelinii with extant Persea leaves based on leaf shape, venation, and epidermal structure.

Laurophyllum sp.

Figures $2 \mathrm{i}-\mathrm{j}$ and $3 \mathrm{a}$

Material: TB.83.369.1; TB.83.380.1; TB.83.399.1; TB.83.493.1; TB.83.508.1; TB.83.533.1; TB.83.540.1

Description (based on TB.83.369.1. and TB.83.493.1.): Fragmentary leaves, length of the fragments more than $5 \mathrm{~cm}$, width 2.3-3 cm. Apex not preserved, base acute. Margin entire. Venation camptodromous, with secondaries arising at angles of 40-60 ${ }^{\circ}$. Secondaries curved and 

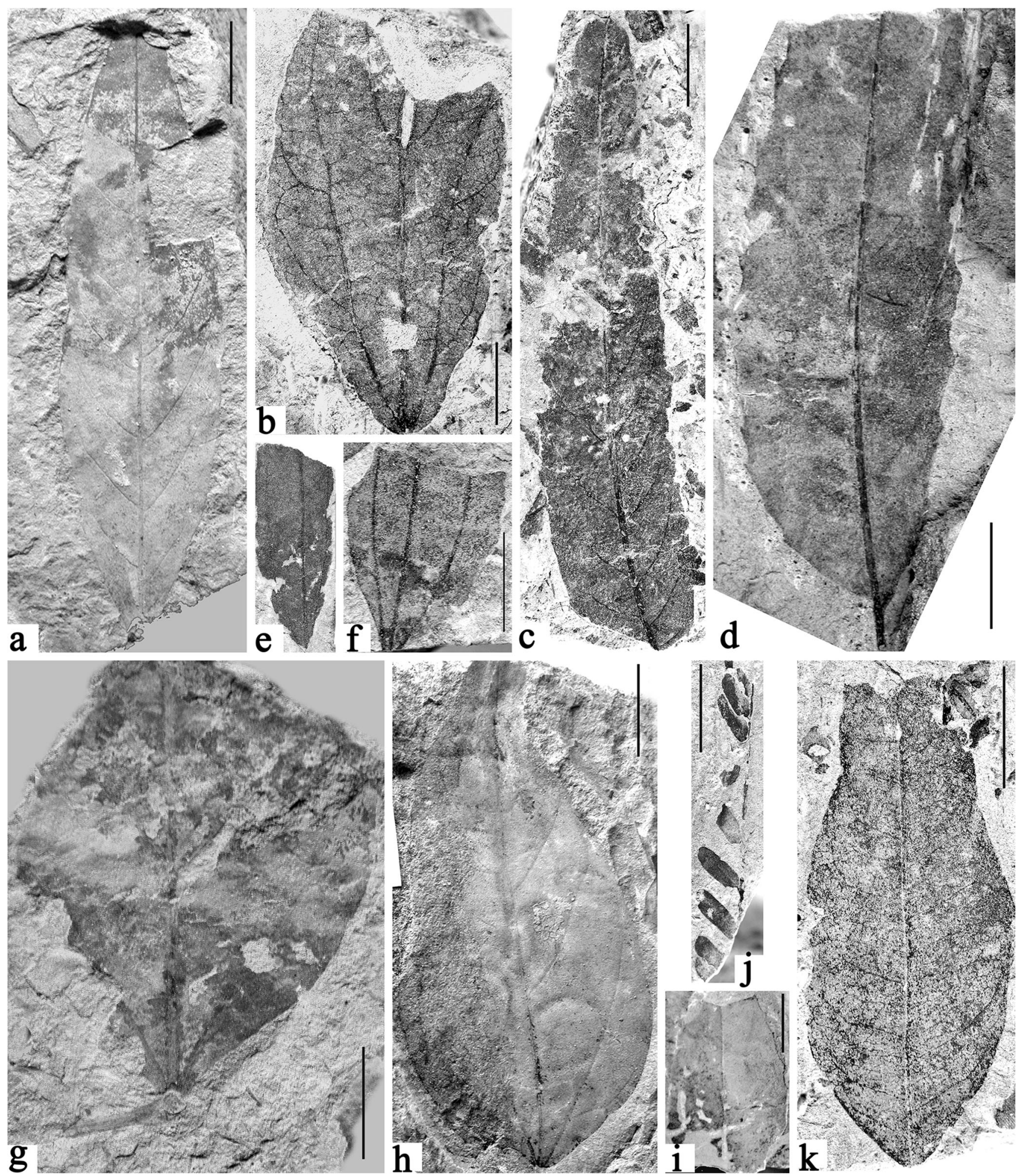

Fig. 3 a Laurophyllum sp., leaf; TB.83.533.1.; scale bar $1 \mathrm{~cm}$. b Daphnogene sp., leaf; TB.83.327.1.; scale bar $0.5 \mathrm{~cm}$. c ?Eotrigonobalanus furcinervis (Rossmässler) Walther et Z. Kvaček, leaf; TB.83.257.1.; scale bar $1 \mathrm{~cm}$. d ?Engelhardia orsbergensis (Weber) Jähnichen, Mai et Walther, leaf; TB.83.540.1.; scale bar $1 \mathrm{~cm}$. e Ziziphus ziziphoides (Unger) Weyland, leaf; TB.83.522.1.; scale bar

$1 \mathrm{~cm}$. f Ziziphus ziziphoides (Unger) Weyland, leaf; TB.83.445.1.; scale bar $1 \mathrm{~cm} . \mathbf{g}$ Byttneriopsis daphnogenes (Ettingshausen) Kvaček et Wilde, leaf; TB.83.432.1.; scale bar $1 \mathrm{~cm}$. h cf. Byttneriopsis sp., leaf; TB.83.429.1.; scale bar $1 \mathrm{~cm}$. i ?Mahonia sp., leaf; TB.83.442.1.; scale bar $1 \mathrm{~cm}$. j Leguminosites sp., leaflets; TB.83.548.1.; scale bar $1 \mathrm{~cm}$. k?Rhodomyrtophyllum sp., leaf; TB.83.315.1.; scale bar $1 \mathrm{~cm}$ 
forming weak loops close to the margin. Epidermal details not preserved.

Discussion: Leaf morphology, entire margin and venation recall leaves of Lauraceae (see Klucking 1987).

?Ocotea Aublet

cf. Ocotea hradekensis (Kvaček et Bůžek) Kvaček

Figure 2f-h

Material: TB.83.385.1

Description: A fragmentary leaf with well-preserved cuticle. Length of the fragment $10 \mathrm{~cm}$, width $2.5 \mathrm{~cm}$. Margin entire, apex and base not preserved. Secondary and higher order venation not preserved.

Adaxial cuticle not preserved. Abaxial cuticle thick and showing a well recognisable arrangement of epidermal cells. Anticlinal cell walls straight and moderately thickened. Epidermal cells isodiametric and $12-30 \mu \mathrm{m}$ in diameter. Stomata randomly arranged, paracytic, 18-24 $\mu \mathrm{m}$ wide and 16-22 $\mu \mathrm{m}$ long. Strongly cutinized outer stomatal ledges surround the 8-12 $\mu \mathrm{m}$ long stomatal pore. No trichomes, trichome bases, or any special ornamentation of the cuticle observed. Amorphous fluorescent patches (?oil glands) appear when using epifluorescence.

Discussion: Although, it represents about two thirds of the original size, its macromorphological traits are hardly recognisable and reveal no details of the venation type. Overall character of the cuticle, type and size of stomata, and the lack of trichome bases fit best to the description of Laurophyllum hradekense Kvaček et Bůžek (Kvaček and Bůžek 1966; Kvaček 1971) later recombined as Ocotea hradekensis (Kvaček in Bůžek et al. 1996). The fossil leaf from Tatabánya is only tentatively assigned to $O$. hradekensis since the anticlinal cell walls are less thickened (though this may be the result of habitat variation) and less undulate compared to $O$. hradekensis (Knobloch and Kvaček 1976; Holy et al. 2012). Stomata are a bit smaller, similar to the size displayed by the stomata of Laurophyllum pseudoprinceps Weyland et Kilpper. However, the latter species has characteristic bead-like thickenings unlike our fossil. Due to the poorly preserved macromorphology of the leaf, the axillary glands at the base of the lower secondaries which were described by Bůžek et al. (1996) as characteristic for the species (see below) cannot be recognised in our specimen.

$O$. hradekensis has been recorded so far mainly from Miocene localities such as in the Oberpfalz (Bavaria, Germany) together with co-occurring thermophilous elements (e.g., Pandanaceae, Zingiberaceae) (Peters 1963), the Lower Lusatian coal seam, the Žitava Basin, N Bohemia, as an element of a rich mastixioid flora of subtropical character (Kvaček 1971; Holŷ et al. 2012), from Ledenice (South Bohemian Basins, Knobloch and Kvaček 1996), and from the early Miocene Cypris Shale (Western
Bohemia, Bůžek et al. 1996). Based on similar epidermal patterns and associated fruit remains, Kvaček (1971) compared the fossil taxon with recent Ocotea (O. foetens Bentham et Hooker). Kvaček (in Bůžek et al. 1996) therefore directly assigned the species to the genus Ocotea as Ocotea hradekensis (Kvaček et Bůžek) Kvaček based on a combination of characters such as type of stomata and axillary glands (at the axils of the basal pair of secondary veins). He mentioned a younger record of the species from the early Pannonian of Romania. An older, Palaeogene occurrence was reported by Hably (1992) from the early Oligocene Tard Clay Formation in Hungary. However, considering the long stratigraphic record, it seems hardly probable that the same species persisted without any changes from the middle Eocene up to the Miocene.

\section{Daphnogene Unger \\ Daphnogene sp.}

Figure 3b

\section{Material: TB.83.327.1}

Description: A small fragmentary leaf of $1.5 \mathrm{~cm}$ width and $2.7 \mathrm{~cm}$ preserved length. Shape elliptic and asymmetric, margin entire. Base obtuse, petiole and apex not preserved. Venation basal acrodromous. The strong basal pair of secondary veins runs into the upper half of the lamina. Relatively strong tertiary veins (at least three on both sides) depart from the basal secondaries and form loops. Higher order venation reticulate.

Discussion: The morphology of the fossil resembles those leaves that are commonly assigned to the collective extinct genus Daphnogene. Although leaves of Daphnogene mostly display a suprabasal pair of strong secondary veins and a more acute base, the overall character of the fossil leaf still is most comparable to this lauraceous genus. However, acrodromous venation occurs in a great number of angiosperm families, e.g., Lauraceae, Hamamelidaceae, Rhamnaceae, Melastomataceae, and Malvaceae. A similar three-veined fossil leaf taxon, Majanthemophyllum Weber has an opposite pair of basal secondaries, but it differs in its tertiary venation (Knobloch et al. 1996).

Fagaceae

?Eotrigonobalanus Walther et Kvaček

?Eotrigonobalanus furcinervis (Rossmässler) Walther et Kvaček

Figure 3c

Material: TB.83.257.1

Description: Upper half of a fragmentarily preserved lanceolate leaf. Preserved length $7.1 \mathrm{~cm}$, width $1.5 \mathrm{~cm}$. Apex not preserved. Margin toothed, teeth small, acute. Venation semicraspedodromous. Midrib straight and moderate, 

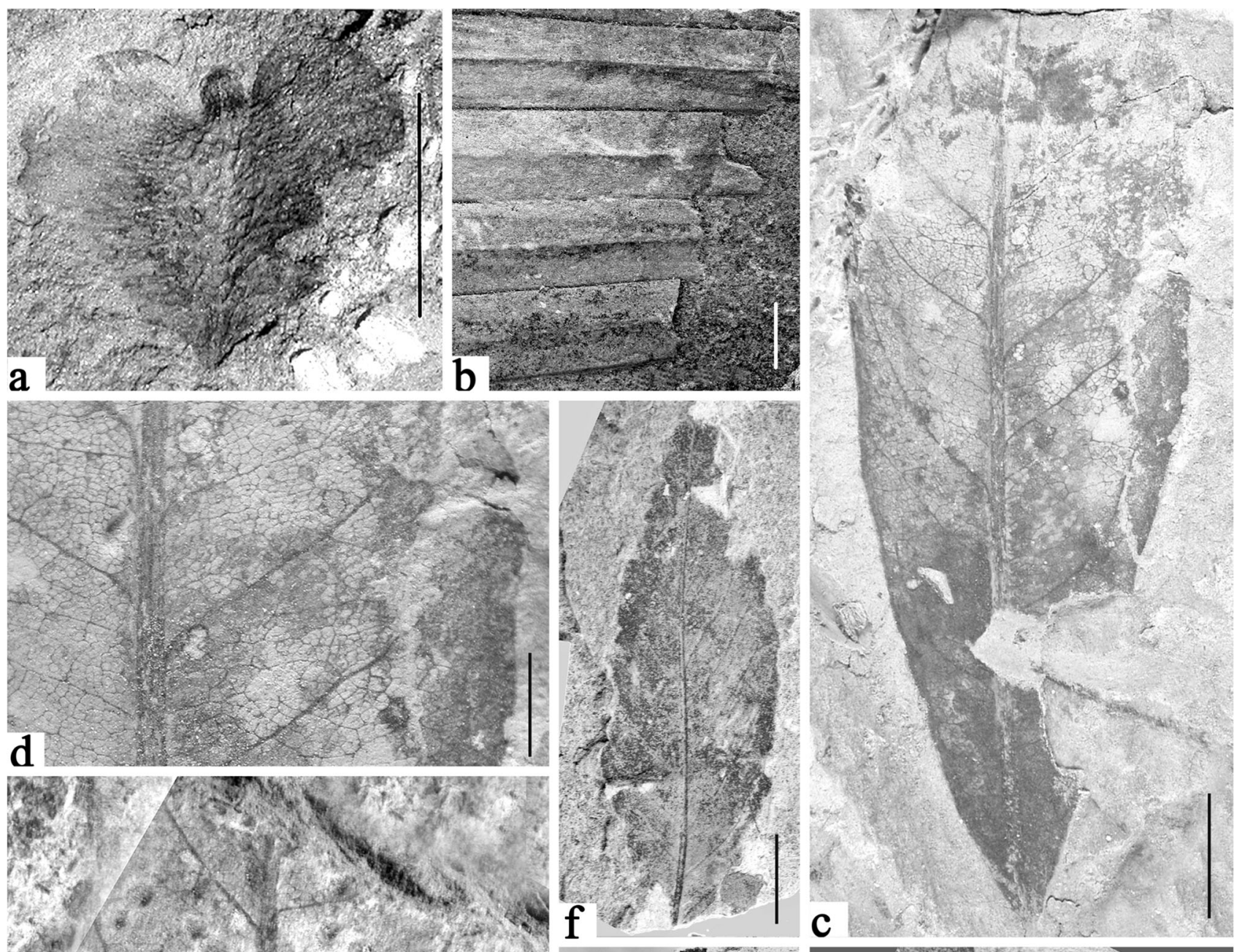

c

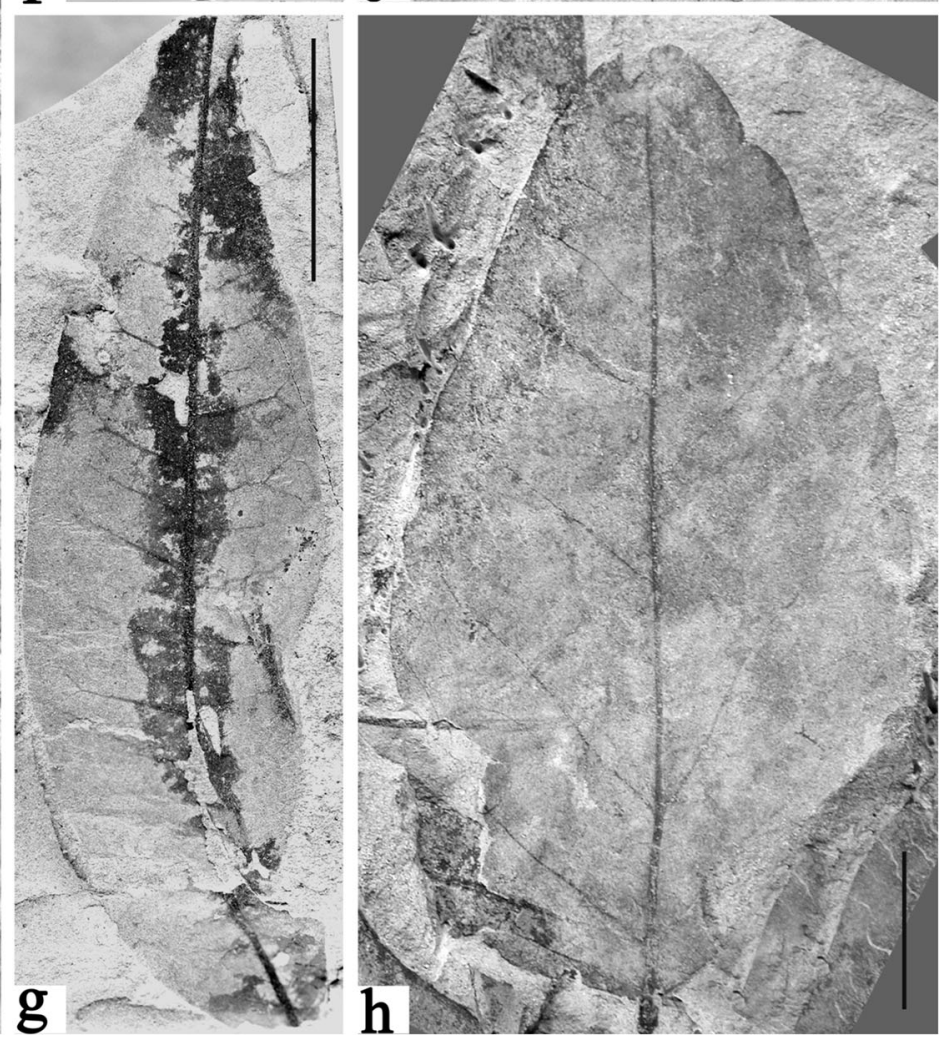

勿 Springer 
Fig. 4 a ?Dioscoreaceae gen. et sp. indet., fruit; TB.83.205.2.; scale bar $1 \mathrm{~cm}$. b Palmae gen. et sp. indet., leaf; TB.83.851.1.; scale bar $1 \mathrm{~cm}$. c, d ?Theaceae gen. et sp. indet., leaf; TB.83.551.1; C, scale bar $1 \mathrm{~cm}$; D, scale bar $0.5 \mathrm{~cm}$. e ?Theaceae gen. et sp. indet., leaf; TB.4; scale bar $1 \mathrm{~cm}$. f Dicotylophyllum sp. 1., leaf; TB.83.596.1.; scale bar $1 \mathrm{~cm} . \mathbf{g}$ Dicotylophyllum sp. 2., leaf; TB.83.567.1.; scale bar $1 \mathrm{~cm}$. h Dicotylophyllum sp. 3., leaf; TB.83.356.1; scale bar $1 \mathrm{~cm}$

secondaries arise at angles of $45-55^{\circ}$ and curve upwards. Higher order veins not preserved.

Discussion: The leaf recalls the morphology of Eotrigonobalanus furcinervis. A wide morphological range of the species was recorded (Kvaček and Walther 1989), i.e., lanceolate to ovate forms, entire to toothed margin, craspedodromous to semicraspedodromous and craspedodromous venation. Due to insufficiently preserved morphological details the leaf is only tentatively assigned to the species.

Eotrigonobalanus furcinervis is a frequent member of Palaeogene floras in Europe (for details, see Kvaček and Walther 1989; Knobloch et al. 1996). Further records of the species based on macromorphology are known from the Eocene flora of Ovce Polje, Macedonia (Mihajlovič and Ljubotenski 1994) and uncertain records from the Eocene flora of Csordakút, Hungary (Erdei and Rákosi 2009). Macroand micromorphologically supported records of the taxon have been reported from the early Oligocene floras of the Hungarian Tard Clay Formation at Budapest-NagybátonyÚjlak brickyard and H-boreholes (Hably 1986; Hably and Manchester 2000).

Juglandaceae

?Engelhardia Leschenault de la Tour ex Blume

?Engelhardia orsbergensis (Weber) Jähnichen, Mai et Walther

Figure 3d

Material: TB.83.540.1.; TB.83.506.1.

Description (TB.83.540.1.): Asymmetric leaf(let), apical part not preserved. Length of the fragment $5 \mathrm{~cm}$, width $2 \mathrm{~cm}$, lamina and base asymmetric, cuneate, with a short petiolule(?) of $3 \mathrm{~mm}$ length. Margin serrate, teeth small, acuminate. Midvein slightly bent, secondaries arise at angles of $45-50^{\circ}$.

Discussion: The overall character of the leaf fragment is comparable to Engelhardia orsbergensis; however, the species has no distinct petioles. The short petiolule-like structure of the fossil may have formed due to infolding of the lamina (see in Jähnichen et al. 1977); however, some extant Engelhardia species, e.g., E. roxburghiana Lindley, carry leaflets with short petiolules. Nevertheless, since no epidermal details are available the fragment is only tentatively assigned to the species.
The species is widespread in the European Palaeogene and Neogene floras, and a frequent element of the Hungarian Cenozoic floras from the early Oligocene (Tard Clay floras) up to the Pliocene (Hably and Kvaček 1998).

\section{Rhamnaceae \\ Ziziphus Miller \\ Ziziphus ziziphoides (Unger) Weyland}

Figure 3e-f

1847 Ceanothus zizyphoides Unger, p.145, Taf. 49, fig. 10

1853 Ceanothus zizyphoides Unger, Ettingshausen, p. 76, Taf. 25, figs. 9-39

1948 Zizyphus zizyphoides (Unger) Weyland, Weyland, pp. 113-118

1975 Zizyphus zizyphoides (Unger) Weyland; Palamarev et Petkova, p. 205, Pl. 3, fig. A

Material: TB.83.206.1; TB.83.207.1; TB.83.223.1; TB.83.227.1; TB.83.255.1; TB.83.275.1; TB.83.286.1; TB.83.297.1; ТВ.83.300.1; TB.83.378.1; ТВ.83.399.1; TB.83.445.1; TB.83.522.1

Description: Leaves fragmentarily preserved, lanceolate, length of the fragments $2-2.8 \mathrm{~cm}$, width $1.1-1.6 \mathrm{~cm}$, petiole not preserved. Base acute, slightly asymmetric, apex not preserved. Margin crenate. Venation basal acrodromous. Midrib moderate and slightly bent. Apart from a pair of stout secondary veins arising at the base finer venation not preserved.

Discussion: The species is a common element of the early Oligocene floras of Hungary (Tard Clay floras; Andreánszky 1963, Hably 1979). Other unequivocal records of the species are not known from the Hungarian Eocene, although an equivocal record was reported from the Eocene of Csordakút (Erdei and Rákosi 2009). Another species, Ziziphus bilinica Ettingshausen, is often merged with $Z$. ziziphoides or maintained as a separate taxon (e.g., Kučlin; Kvaček and Teodoridis 2011) indicating that the European fossils of the genus still require revision (Kvaček and Teodoridis 2011).

The frequent occurrence of the species in Palaeogene assemblages of the eastern part, such as Häring (Austria; Ettingshausen 1853), Sotzka (Slovenia; Unger 1847), Ovce Polje (Macedonia; Mihajlovič and Ljubotenski 1994), and Bulgaria (Palamarev and Petkova 1975), may indicate a subhumid character of the vegetation of parts of Central and Southeastern Europe for the respective time.

Malvaceae s.l.

Byttneriopsis Kvaček et Wilde

Byttneriopsis daphnogenes (Ettingshausen) Kvaček et Wilde Figure $3 \mathrm{~g}$

Material: TB.83.432.1, ?TB.2. 
Description: Fragmentarily preserved leaf (lower half) of $3.2 \mathrm{~cm}$ length and $2.8 \mathrm{~cm}$ width. Leaf with long petiole (more than $1 \mathrm{~cm}$ long, robust, $2 \mathrm{~mm}$ wide, pulvinate and geniculate). Leaf entire margined, base cuneate, venation basal acro-dromous with three strong primaries (threeveined). Higher order venation not preserved.

Discussion: The morphological description of the leaf is well comparable to that of the fossil genus Byttneriopsis (Kvaček and Wilde 2010). It accommodates simple, non-lobate, entire margined leaves with a characteristic long petiole, basal acrodromous venation, and barrel shaped glandular trichomes suggesting malvalean affinities (Kvaček and Wilde 2010). The leaf is assigned to Byttneriopsis daphnogenes based on the distinctly pulvinate and geniculate petiole, triveined ivenation, and cuneate base). This morphospecies was ireported from various Eocene sites of Europe, including Lábatlan in Hungary, Messel in Germany, and Kučlin in the Czech Republic (Kvaček and Wilde 2010). The putative imodern analogues of Byttneriopsis grow under subtropicalparatropical conditions (Kvaček and Wilde 2010).

\section{cf. Byttneriopsis sp.}

Figure $3 \mathrm{~h}$

\section{Material: TB.83.429.1}

Description: Leaf of $6.5 \mathrm{~cm}$ length and $2.9 \mathrm{~cm}$ width, ovate with entire margin, apex acuminate, base cuneate, petiole not preserved. Venation basal acrodromous with the basal veins arising directly from the base of the lamina, midrib moderate, basal veins curved, reaching up to nearly the half of the lamina, giving off loop-forming lateral veins. Higher order venation dense, orthogonal reticulate.

Discussion: The morphological description of the leaf fits well to that of the morphogenus Byttneriopsis (Kvaček and Wilde 2010). Since petiole and characteristic epidermal details of the leaf are not preserved the leaf is only tentatively assigned to the genus.

Leaves with similar morphology were described as cf. Matudaea menzelii Walther from the Tard Clay Formation (early Oligocene, Kiscellian) of Hungary (p. 9, Pl. 5, Figs. 1-6; Kvaček and Hably 1998). However, they differ in having two strong lateral veins arising slightly above the base (suprabasal acrodromous). Unfortunately, the material from the Tard Clay also lacks cuticles. Leaves of Daphnogene may show some similarities in their acrodromous venation (see, e.g., Wilde 1989), but venation is mostly suprabasal.

Berberidaceae

?Mahonia Nuttall

?Mahonia sp.

Figure $3 \mathrm{i}$

Material: TB.83.442.1.
Description: Leaf(?let) fragmentary, $3.1 \mathrm{~cm}$ long and $2 \mathrm{~cm}$ wide. Shape ovate, apex and base not preserved. Margin toothed, dentate, with few coarse teeth. Venation not preserved except for a stout midvein.

Discussion: The overall character of the fossil with its shape, margin, and texture, recalls Mahonia leaflets. Due to its fragmentary state and the lack of preservation in higher order venation, the fossil cannot be assigned to Mahonia with certainty. The earliest Mahonia fossils in Europe were described from the early Oligocene (Bůžek et al. 1990; Güner and Denk 2012).

Leguminosae

Leguminosites Bowerbank emend. Schimper Leguminosites $\mathrm{sp}$.

Figure $3 \mathrm{j}$

Material: TB.83.548.1.

Description: Leaf compound, 8 leaflets preserved. Basal and apical parts of leaf not preserved. Leaflets sessile, narrow oblong, $0.6-0.8 \mathrm{~cm}$ long and $0.2-0.3 \mathrm{~cm}$ wide. Base acute, asymmetric, apex rounded. Margin entire. Venation not preserved.

Discussion: The compound leaf strongly recalls Leguminosae; however, closer affinities are uncertain.

Myrtaceae

? Rhodomyrtophyllum Rüffle et Jähnichen

?Rhodomyrtophyllum sp.

Figure 3k

Material: TB.83.315.1; TB.83.453.1.

Description: Narrow elliptic leaves, length of the fragments 3.8 $4.2 \mathrm{~cm}$, width $1.8-1.9 \mathrm{~cm}$, petiole not preserved. Base acute, or nearly obtuse, apex not preserved. Margin entire. Venation eucamptodromous with dense and comparatively fine secondary and intersecondary venation. Midrib moderate and straight. Secondaries arise at angles of $70-80^{\circ}$, join the adjacent secondaries near the leaf margin and form loops. Finer intersecondary veins arise at the same angles between the secondaries. Tertiary venation appears reticulate. Cuticle not preserved.

Discussion: Such ovate leaves with dense secondary and intersecondary venation arising nearly perpendicular from the midvein resemble leaves that were assigned to Myrtaceae, e.g., Rhodomyrtophyllum reticulosum (Rossmässler) Knobloch et Kvaček in Knobloch et al. (1996), R. sinuatum (Bandulska) Walther in Mai and Walther (1985), or R. rossmässleri Rüffle et Jähnichen (1976). The fossils may well belong to Rhodomyrtophyllum; however, we refrained to assign the leaves with certainty due to the lack of cuticular details. Rhodo-myrtophyllum leaves were mainly described from Eocene localities of Europe; those confirmed by cuticular structures are from Messel (Wilde 1989), the Weißelster Basin (Mai and Walther 1985), Staré Sedlo (Knobloch et al. 1996), and the Geiseltal (Rüffle and Jähnichen 


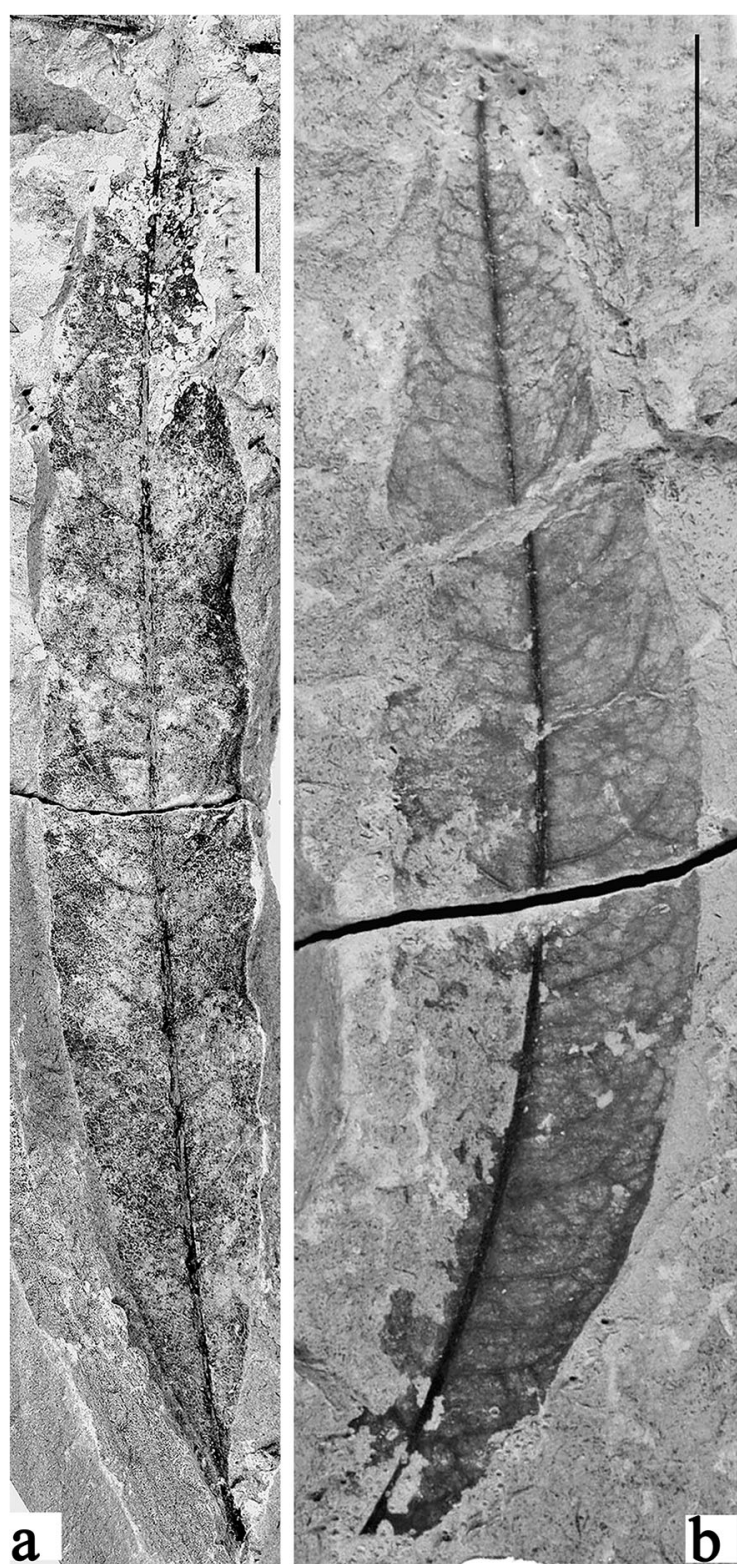

Fig. 5 a Dicotylophyllum sp. 4., leaf; TB.5.; scale bar $1 \mathrm{~cm}$. b Dicotylophyllum sp. 5., leaf; TB.83.417.1.; scale bar $1 \mathrm{~cm}$. c Dicotylophyllum sp. 6., leaf; TB.83.378.1.; scale bar $1 \mathrm{~cm}$. d Dicotylophyllum sp. 6., leaf; TB.83.378.1.; scale bar $1 \mathrm{~cm}$. e

1976), etc. The only Hungarian record (also lacking cuticular details) of Rhodomyrtophyllum ( $R$. rossmässleri) was published from the early Oligocene Tard Clay floras (Budapest, H-boreholes, Hably 1979).

\section{Theaceae}

?Theaceae gen. et sp. indet.

Figure 4c-e

Material: TB.83.551.1; TB.4.

Description (TB.83.551.1): Fragmentary leaf, length $6.2 \mathrm{~cm}$, width $2.5 \mathrm{~cm}$. Leaf elliptic, slightly obovate, base cuneate,

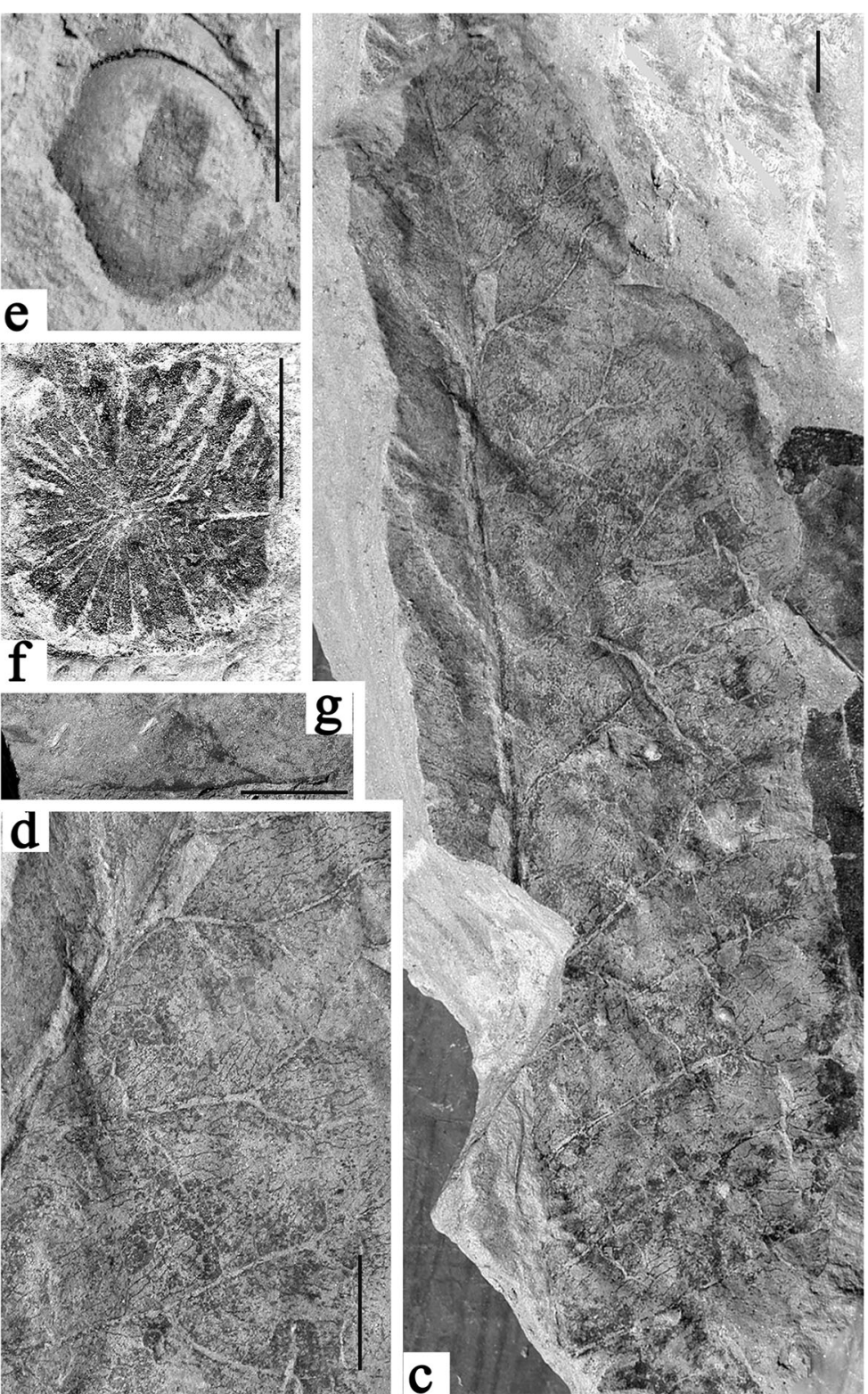

Carpolithes sp. 1., fruit or seed; TB.83.421.1; scale bar $1 \mathrm{~cm}$. f Carpolithes sp. 2., ?fruit; TB.83.339.1; scale bar $1 \mathrm{~cm}$. g Carpolithes sp. 3. (?Ailanthus sp.), fruit; TB.83.474.1; scale bar $1 \mathrm{~cm}$

apex not preserved, margin ?entire. Venation camptodromous, midvein stout, secondaries irregularly spaced, decurrent along midvein, arising at angles of $45-50^{\circ}$. Mostly fine intersecondaries, irregularly spaced, arising at various angles. Tertiary veins reticulate, between tertiaries freely ending branched veinlets.

Another leaf fragment (TB.4.) is petiolate and more ovate than the previous leaf, but shows a venation pattern with decurrent secondaries well comparable to the first leaf.

Discussion: Venation pattern, especially decurrent secondary veins, and overall leaf morphology resemble leaves of Theaceae (e.g., Adinandra Jack, Eurya Thunberg, Gordonia 
J. Ellis, Stewartia I. Lawson).

Dioscoreaceae

?Dioscoreaceae gen. et sp. indet.

Figure 4a

Material: TB.83.205.2.

Description: Impression of a winged fruit of $1.4 \mathrm{~cm}$ length and $1.7 \mathrm{~cm}$ width. Fruit symmetrical, widely elliptic, with persistent epigynous calyx, at least two wings. Base narrowing into a pedicel, endocarp centrally positioned. Wing margin entire, marginal vein or thickening present. Venation pattern dichotomizing and anastomosing, veins radiating outwards, no suture observable.

Discussion: The clearly preserved epigynous perianth and the overall structure of the fruit recalls Dioscoreaceae (?Dioscorea L.) fruits. However, a strong median suture as seen in the modern fruits is not observable, which may be due to preservation. In Dioscoreaceae, fruits develop from a tricarpellate inferior ovary and an epigynous perianth often persists (Manchester and O'Leary 2010). Other fruits with epigynous perianth resembling the fossil belong to Combretaceae or Lecithydaceae. The wings of comparable fruits in Combretaceae have usually no distinct marginal vein/thickening. Fruits of Petersianthus Merrill (Lecithydaceae) are much larger than our fossil and have characteristic but different venation patterns of the wings (see Manchester and O'Leary 2010).

Comparable fruits (but with definite median suture) were described as Dioscoreocarpum marginatum Andreánszky from the early Oligocene flora of Eger-Kiseged (Tard Clay; Andreánszky 1959; see also Raz 2017). Other fruits were reported as ?Dioscorea from the late Eocene flora of Kučlin (Czech Republic; Kvaček and Teodoridis 2011). Today, members of Dioscoreaceae are plants with a liana-like or climbing habit.

\section{Arecaceae}

Palmae gen. et sp. indet.

Figure $4 b$

Material: TB.83.202.1; TB.83.204.1; TB.83.391.1; TB.83.535.1; TB.83.851.1

Description: Fragmentary remains of leaf segments, width of individual segments $1.2-1.5 \mathrm{~cm}$, margin of segments entire. Basal or apical parts of segments not preserved.

Discussion: The fossil leaves probably represent a sabaloid palm; however, precise identification is not possible since the basal part of the segments is not preserved. Palms are represented in the Palaeogene of Hungary, though, not frequently. No palms were recorded in the coeval flora of Csordakút (Erdei and Rákosi 2009). From the early Oligocene floras of the Tard Clay Formation, some fossils were assigned to (sabaloid) palms, e.g.,
Sabal haeringiana Unger (Rásky 1943).

Angiospermae fam. indet.

Dicotylophyllum Saporta

Dicotylophyllum sp. 1.

Figure 4f

Material: TB.83.199.1; TB.83.361.1; TB.83.596.1.

Description (TB.83.596.1): Leaf fragmented, lamina elliptic, length $5.8 \mathrm{~cm}$, width $2 \mathrm{~cm}$. Apex and base not preserved but presumably both acute (?cuneate). Margin hardly observable, damaged, seems toothed, teeth details not available. Venation seems craspedodromous, midvein slightly curved, moderate, secondaries regularly spaced, at least 12 pairs, arise at $45-50^{\circ}$, run slightly bent toward the margin. Higher venation not preserved. Discussion: According to shape and venation, these leaves may represent Fagaceae or Ulmaceae.

\section{Dicotylophyllum sp. 2.}

Figure 4g

Material: TB.83.567.1.

Description: Leaf asymmetric, lanceolate, $4.7 \mathrm{~cm}$ long and $1.2 \mathrm{~cm}$ wide. Base asymmetric, acute, apex attenuate. Margin entire. Venation cladodromous, midvein moderate, slightly curved. Secondaries (min. 11 pairs) arising at angles of $60-70^{\circ}$, run straight and fork near the margin. Delicate intersecondaries arise at the same angles as secondaries and run straight. Higher order venation not preserved.

Discussion: Leaf shape, entire margin, and type of venation may refer to Anacardiaceae.

Dicotylophyllum sp. 3.

Figure 4h

Material: TB.83.356.1.

Description: Simple petiolate leaf. Lamina symmetric, $6 \mathrm{~cm}$ long, $3.2 \mathrm{~cm}$ wide, elliptic. Petiole short, $25 \mathrm{~mm}$ long and relatively stout. Base obtuse, apex obtuse, and nearly rounded. Margin entire, slightly wavy. Venation eucamptodromous, midvein relatively thin and straight. Secondaries ( 8 pairs) arising at angles of $45-60^{\circ}$, slightly irregular in course and spacing, the lowermost pair arises close to the base at an angle of about $70^{\circ}$. Most pairs of secondaries opposite, rarely alternate, running nearly straight, curved near the margin. Higher order venation not preserved.

Dicotylophyllum sp. 4.

Figure 5a

Material: TB.83.419.1; TB.83.494.1; TB.83.506.1; 
TB.83.546.1; TB.5; TB.83.566.1

Description: Narrow elliptic to lanceolate, slightly asymmetric leaves, length of the only complete leaf $15.2 \mathrm{~cm}$, width 2$2.3 \mathrm{~cm}$, the others are fragmentary. Petiole $0.4 \mathrm{~cm}$ long. Base acute, cuneate, apex attenuate. Margin entire but irregularly wavy. Venation eucampto-dromous, midrib stout and slightly curved. Secondaries curved arising at angles of 60$70^{\circ}$, some intersecondary veins less steeply arising. Higher order venation not preserved.

Discussion: Such entire-margined leaves with eucamptodromous venation may represent species of Lauraceae or Fagaceae.

\section{Dicotylophyllum sp. 5.}

Figure 5b

Material: TB.83.417.1; TB.83.438.1; (broken halves of a single specimen)

Description: Leaf asymmetric, lanceolate, $10.5 \mathrm{~cm}$ long and $2.3 \mathrm{~cm}$ wide. Base not preserved, apex attenuate. Margin entire. Venation eucamptodromous, midvein moderate, curved in the lower half. High number of upward curving secondaries (min. 16 pairs) arise at angles of $60-70^{\circ}$. Intersecondaries (sometimes even two) arise between secondaries at angles of $60-80^{\circ}$. Adjacent secondaries and intersecondaries join to form loops or run towards the margin. Tertiary venation reticulate.

Discussion: The morphological characters of the leaf recall some Lauraceae (e.g., Litsea Lamarck, see Klucking 1987).

Dicotylophyllum sp. 6.

Figure 5c-d

\section{Material: TB.83.378.1.}

Description: Fragment of a large leaf, lamina most probably elliptic, length of the fragment $16 \mathrm{~cm}$, width $5 \mathrm{~cm}$. Apex and base not preserved. Entire and irregularly wavy margin only preserved on a short length. Venation irregular, cladodromous. Midvein straight, relatively stout. Secondary veins slightly decurrent, arising at angles of $45-50^{\circ}$, irregularly running, forking once or twice close to the margin. Tertiary veins forming an irregularly ramified network.

Discussion: Size of the leaf and decurrent irregularly forking secondaries remind of some Magnoliaceae.

\section{Carpolithes sp. 1.}

Figure 5e

Material: TB.83.421.1.

Description: Mold of a fruit or seed, diameter $1.3 \mathrm{~cm}$, with basal scar, no ornamentation preserved.

Carpolithes sp. 2.

Figure $5 \mathrm{f}$
Material: TB.83.339.1

Description: Impression of an ?infructescence with a diameter $1.8 \mathrm{~cm}$, elongate bracts or ?fruitlets radially arranged.

Carpolithes sp. 3. (?Ailanthus sp.)

Figure $5 \mathrm{~g}$

Material: TB.83.474.1.

Description: An incompletely preserved winged fruit, length of the fragment $32 \mathrm{~mm}$, width $9 \mathrm{~mm}$. Roundish seed of $4 \mathrm{~mm}$ diameter, centrally positioned. No venation preserved except for an intramarginal vein or thickening.

Discussion: Especially due to shape and centrally positioned seed the fossil may represent an Ailanthus Desfontaines samara. Fruits of Ailanthus were mostly recorded from the Oligocene and Miocene of Europe (see for details Hably 2001), including numerous samaras from the early Oligocene Tard Clay flora (Nagybátony-Újlak brickyard). Ailanthus fruits are also known from Eocene localities in Central Europe (e.g., Kučlin, Kvaček and Teodoridis 2011; Messel, Collinson et al. 2012; see also Corbett and Manchester 2004).

\section{Flora and vegetation}

The leaf assemblage from Tatabánya dominantly comprises remains of angiosperms. Gymnosperms may be represented by a single specimen of a coniferous twig and ferns by a single tiny fragment of a pinna or pinnule. Angiosperms represented by cuticles are two species of Lauraceae, Laurophyllum ?kinkelinii and cf. Ocotea hradekensis. Other leaves which are putatively regarded as Lauraceae based on leaf shape and venation were assigned to Daphnogene and Laurophyllum. Furthermore, there are leaves of Rhamnaceae (Ziziphus ziziphoides), Malvaceae s.l. (Byttneriopsis), Leguminosae, Myrtaceae, and Palmae and other taxa are regarded as probable, such as Berberidaceae (?Mahonia), Dioscoreaceae, Fagaceae (?Eotrigonobalanus), Anacardiaceae, Juglandaceae (?Engelhardia), and Theaceae.

The rarity of gymnosperms in the fossil assemblage may either reflect their subordinate role in the vegetation or can be attributed to the depositional setting. In any case, the poor preservation and fragmentation of most of the leaf fossils indicate considerable transport and sorting which could be an alternative explanation for the rarity of gymnosperms.

The taphocoenosis is dominated by long lanceolate leaves which are characterised by entire to slightly wavy margin. Lauraceae, Rhamnaceae (Ziziphus), and fragments of palm leaves are frequent elements of the assemblage; however, considering longer transport, some of them may be over-represented due to an originally resistant, coriaceous texture. As rare 
elements, Malvaceae s.l., Myrtaceae, and Leguminosae as well as putative Berberidaceae, Dioscoreaceae, Anacardiaceae, Juglandaceae, and Theaceae should be mentioned.

The taphocoenosis is dominated by dicotyledonous arboreal plants and palms. Remains of herbaceous elements, e.g., ferns, are extremely rare and aquatic or helophytic plants are totally missing. Although a reconstruction of the composition of the original vegetation is hardly feasible based on the poor fossil record, an evergreen character may be indicated by the morphology of the leaves; entire-margined leaves are dominating and a high number of the taxa probably had a coriaceous texture originally (Lauraceae spp., ?Mahonia sp., ?Rhodomyrtophyllum sp., Dicotylophyllum sp. 4). The frequent occurrence of Ziziphus and leaves with entire and slightly wavy margin and coriaceous texture (e.g., Dicotylophyllum sp. 4) as well as small-leaved Leguminosae may suggest subhumid conditions and a xerophytic character of the original vegetation.

The palynological studies of Kedves (1962a, 1962b) provide additional information on the vegetation of the Tatabánya coal basin, which was not uniform according to his results. The palynoflora of the northern coal field shows similarities to that of Dorog, and the palynofloras of the southern and western coal fields are comparable to those of Halimba (and Dudar). Based on the palynological spectra, the Dorog, Halimba, and Dudar floral districts were distinguished by Kedves (1962a, 1962b) for the Eocene. He argued that Dorog was characterised by open swamp conditions in the littoral region together with TaxodiaceaeCupressaceae swamp forests, palms, Myricaceae, and Sequoia forests. The Halimba sequences suggest Castanea on higher levels, as well as Myricaceae, Sapotaceae, and Palmae. Kedves attributed the disparity of these floral districts to different ecological conditions. The Eocene palynological spectra of Hungary led Kedves (1960) to infer a tropical climate for the area in general.

The results of our study of the macroflora show a picture with a high frequency of leaves representing Lauraceae and the extreme rarity of gymnosperms.

\section{Comparisons with Eocene and early Oligocene assemblages of Hungary and Europe}

The middle Eocene flora of Csordakút (Erdei and Rákosi 2009) was preserved in a lacustrine facies, while the Tatabánya assemblage in contrast was recovered from marine clays and marls. A similar character of the Tatabánya and Csordakút assemblages is the absence of gymnosperms. Shared taxa are Lauraceae, Ziziphus ziziphoides, Leguminosae, ?Eotrigonobalanus, and ?Anacardiaceae. Remains of palms are missing from Csordakút, whereas Sloanea Linnaeus, Cedrelospermum, and Myricaceae were not found at Tatabánya but recorded at Csordakút. Furthermore, the lanceolate leaf type (Dicotylophyllum sp. 4: ?Lauraceae vel Fagaceae) which is characterised by an entire, slightly wavy leaf margin, and possibly had a coriaceous texture, dominates the Tatabánya assemblage but was not recognised in the taphocoenosis of Csordakút. Such disparities in the macroremains most probably reflect the different facies of the two localities. Although the Eocene flora of Lábatlan (Kovács $1959,1961)$ needs future revision, it can be noted already that the subordinate role of gymnosperms is common to other Eocene macro-assemblages from Hungary.

In contrast to the Eocene macro-assemblages being devoid of gymnosperm remains, the flora of the early Oligocene Tard Clay Formation (NP23 nannoplankton zone) is well characterised by conifers (Kvaček and Hably 1998), like Doliostrobus taxiformis (Sternberg) Kvaček var. hungaricus (Rásky) Kvaček et Hably, and Tetraclinis salicornioides (Unger) Kvaček as well as $T$. brachyodon (Brongniart) Mai et Walther, Calocedrus suleticensis (Brabenec) Kvaček, Chamaecyparites hardtii (Göppert) Endlicher, etc. Even cycads are represented by the remains of Ceratozamia floersheimensis (Engelhardt) Kvaček (Kvaček 2002). Winged fruits, which show a high diversity in the Tard Clay flora, are nearly missing in the Tatabánya assemblage. Features shared by the Tard Clay floras and the Tatabánya assemblage are the abundance of Lauraceae (Laurophyllum div. sp.), and the occurrence of taxa, like Ziziphus ziziphoides, Palmae, ?Eotrigonobalanus furcinervis. Remains of Sloanea are quite characteristic of the Tard Clay floras, but were not recorded at Tatabánya. Daphnogene leaves are frequent in the Tard Clay flora, but only represented by a single specimen in the Tatabánya assemblage. The subhumid character of the Tard Clay assemblage (Erdei et al. 2012) can also be recognised at Tatabánya which is confirmed by the frequent occurrence of Ziziphus together with long narrow leaves with entire and slightly wavy margin (Dicotylophyllum sp. 4; Lauraceae vel Fagaceae) and small-leaved Leguminosae.

Since the Tatabánya assemblage is dominated by impressions and cuticles are rarely preserved, a systematic comparison with other European Eocene floras is limited. However, some general notes should be made. A subhumid character of the vegetation similar to Tatabánya is often suggested by the early Palaeogene floras of eastern Central Europe and Southeastern Europe, e.g., by the early Oligocene flora of Häring in Tirol (Ettingshausen 1853), the Tard Clay floras (Hably 2006; Erdei et al. 2012), Eocene to early Oligocene floras of Serbia and Macedonia (Mihajlovič and Ljubotenski 1994), and the late Eocene flora of Ovče Polje (Macedonia; Mihajlovič and Ljubotenski 1994). Similar to the Eocene macrofloras of Hungary, the Eocene Girbou assemblage in Romania (Petrescu et al. 1976) is devoid of gymnosperm remains.

The Eocene floras from Central/Western Europe generally do not show a subhumid character. The late Eocene flora of Staré Sedlo in Bohemia (Knobloch et al. 1996) and the early Palaeogene floras of the Weisselster Basin, Messel, and the 
Geiseltal in Germany (Rüffle 1976; Rüffle et al. 1976; Mai and Walther 1978; Wilde 1989) are all devoid of Ziziphus but share Lauraceae, Leguminosae, Palmae, and (?)Eotrigonobalanus (missing in Messel) with the Tatabánya flora. Interestingly, the tropical-subtropical genus Sloanea, which preferred mesic habitats and was a frequent element of Eocene floras in Bohemia (Kučlin), the Weisselster Basin (Kvaček and Teodoridis 2011), Messel (Collinson et al. 2012), or even Csordakút in Hungary (Erdei and Rákosi 2009), is missing in the Tatabánya assemblage.

\section{Climate and vegetation}

Based on the leaf physiognomic characters, a broad-leaved evergreen forest thrived in the source area for the middle Eocene taphocoenosis of the Tatabánya region. The ratio of entire-margined leaves is quite high, 79\% (total number of leaves 323), higher than measured for the Messel assemblage (57\%, total number of leaves 1078) or the Tard Clay flora (61\%, total number of leaves 2239$)$ but close to values obtained for the flora of Kučlin (>70\%, Kvaček and Teodoridis 2011). The high ratio of entire-margined leaves in Tatabánya may be attributable to the relatively low sample size; however, taphonomic factors such as sorting and differential preservation may have been more important for selection. Palaeoclimate estimates of some European Eocene floras (e.g., Kučlin, Staré Sedlo, floras of the Weisselster Basin and Saxony, Messel) adopting CLAMP, LMA, or CA methods showed a frost-free climate with a mean annual temperature higher than $16 \mathrm{C}^{\circ}$ (see Roth-Nebelsick et al. 2004; Mosbrugger et al. 2005; Kvaček and Teodoridis 2011; Grein et al. 2011). Comparable temperatures were obtained for the early Oligocene Tard Clay floras (Erdei et al. 2012) and may also be inferred for the Tatabánya flora.

\section{Data accessibility}

Specimens studied are housed in the palaeobotanical collection of the Kuny Domokos Museum, Tata, Hungary. Full details of studied collection material, inventory numbers, applied methodology, and locality data are provided in the text.

Acknowledgements $\mathrm{BE}$ is grateful to the Forschungsinstitut Senckenberg for supporting a trip to Frankfurt. In addition thanks are expressed also to Mária Báldi-Beke for studying microfossils and to Lilla Hably, Steven Manchester, and two anonymous reviewers for their useful comments. VW also acknowledges support by the Forschungsinstitut und Naturmuseum Senckenberg for a trip to Budapest.

Funding information Open access funding provided by Hungarian Natural History Museum (MTM). This study was supported by the
National Research, Development and Innovation Office (NKFIHOTKA 120123).

\section{Compliance with ethical standards}

Conflict of interest The authors declare that they have no conflict of interest.

Open Access This article is distributed under the terms of the Creative Commons Attribution 4.0 International License (http:// creativecommons.org/licenses/by/4.0/), which permits unrestricted use, distribution, and reproduction in any medium, provided you give appropriate credit to the original author(s) and the source, provide a link to the Creative Commons license, and indicate if changes were made.

\section{References}

Andreánszky, G. (1951). Adatok a hazai harmadkori flóra ismeretéhez. (Contributions a l'étude de la flore Tertiaire de la Hongrie.). Földtani Közlöny (Bulletin of the Hungarian Geological Society), 81, 320328.

Andreánszky, G. (1954). Ösnövénytan. (Palaeobotany). Budapest pp. 320.

Andreánszky, G. (1959). Contribution à la connaissance de la Flore de l'oligocene inferieur de la Hongrie et un essai sur la reconstitution de la Flore contemporaine. Acta Botanica Hungarica, 5(1-2), 1-37.

Andreánszky, G. (1963). Beiträge zur Kenntniss der Unter-Oligozänen Flora der Umgebung von Budapest. Acta Botanica Hungarica, 9, 3-4.

Báldi-Beke, M. (1984). The nannoplankton of the Transdanubian Palaeogene formations. Geologica Hungarica Series Palaeontologica, 43, 1-222.

Bůžek, Č., Fejfar, O., Konzalová, M., \& Kvaček, Z. (1990). Floristic changes around Stehlin's Grand Coupure in Central Europe. In E. Knobloch \& Z. Kvaček (Eds.), Proceedings of the symposium "Paleofloristic and Paleoclimatic changes in the Cretaceous and Tertiary 1989” (pp. 167-181). Prague: Geological Survey Publisher.

Bůžek, Č., Holý, F., \& Kvaček, Z. (1996). Early Miocene flora of the Cypris shale (Western Bohemia). Acta Musei Nationalis Pragae, Series B, Historia Naturalis, 52(1-4), 1-72.

Collinson, M. E., Manchester, S. R., \& Wilde, V. (2012). Fossil fruits and seeds of the Middle Eocene Messel biota, Germany. Abhandlungen der Senckenberg Gesellschaft für Naturforschung, 570, 1-251.

Corbett, S. L., \& Manchester, S. R. (2004). Phytogeography and fossil history of Ailanthus (Simaroubaceae). International Journal of Plant Sciences, 165(4), 671-690.

Erdei, B., \& Wilde, V. (2004). An Oligocene leaf assemblage from Csolnok, Dorog Basin, N Hungary. Revue de Paléobiologie, 23(1), 117-138.

Erdei, B., \& Rákosi, L. (2009). The middle Eocene flora of Csordakút (N Hungary). Geologica Carpathica, 60(1), 43-57.

Erdei, B., Utescher, T., Hably, L., Tamás, J., Roth-Nebelsick, A., \& Grein, M. (2012). Early Oligocene continental climate of the Palaeogene Basin (Hungary and Slovenia) and the surrounding area- a complex approach. Turkish Journal of Earth Sciences, 21, 153-186.

Ettingshausen, C. (1853). Die Tertiärflora von Häring in Tirol. Abhandlungen der Kaiserlich-königlichen Geologischen Reichanstalt, 2, 1-118.

Grein, M., Utescher, T., Wilde, V., \& Roth-Nebelsick, A. (2011). Reconstruction of the middle Eocene climate of Messel using palaeobotanical data. Neues Jahrbuch für Geologie und Paläontologie Abhandlungen, 260(3), 305-318. 
Güner, T. H., \& Denk, T. (2012). The genus Mahonia in the Miocene of Turkey: taxonomy and biogeographic implications. Review of Palaeobotany and Palynology, 175, 32-46.

Hably, L. (1979). Some data to the Oligocene flora of the Kiscellian Tard Clay, Hungary. Annales historico-naturales Musei nationalis hungarici, 71, 33-53.

Hably, L. (1985). New data to the Eocene flora of Hungary. Annales historico-naturales Musei nationalis hungarici, 77, 25-33.

Hably, L. (1986). The macroflora of the borehole Kiscell-1 in Budapest. Annales historico-naturales Musei nationalis hungarici, 78, 31-40.

Hably, L. (1992). New data to the macroflora of the Tard Clay Formation on the basis of cuticular analysis. Courier Forschungsinstitut Senckenberg, 147, 369-381.

Hably, L. (2001). Fruits and leaves of Ailanthus Desf. from the Tertiary of Hungary. Acta Palaeobotanica, 41(2), 207-219.

Hably, L. (2006). The flora of the Tard Clay Formation and its palaeogeographic implications. Advances in palaeobotanyrecognizing the contributions of David L. Dilcher and Jack A. Wolfe on the occasion of their 70th year, Gainesville, Florida, Abstracts 29.

Hably, L., \& Kvaček, Z. (1998). Pliocene mesophytic forests surrounding crater lakes in western Hungary. Review of Palaeobotany and Palynology, 101(1-4), 257-269.

Hably, L., \& Manchester, S. R. (2000). Fruits of Tetrapterys (Malpighiaceae) from the Oligocene of Hungary and Slovenia. Review of Palaeobotany and Palynology, 111(1-2), 93-101.

Hably, L., Erdei, B., \& Selmeczi, I. (2015). A late Oligocene flora from Környe, near Tatabánya, N Hungary. Neues Jahrbuch für Geologie und Paläontologie, 276(3), 285-302.

Holŷ, F., Kvaček, Z., \& Teodoridis, V. (2012). A review of the early Miocene mastixioid flora of the Kristina mine at Hrádek nad Nisou in North Bohemia (the Czech Republic). Acta Musei Nationalis Pragae, Series B-Historia Naturalis, 68(3-4), 53-118.

Jähnichen, H., Mai, D. H., \& Walther, H. (1977). Blätter und Früchte von Engelhardia LESCH. ex BL. (Juglandaceae) aus dem europäischen Tertiär. Feddes Repertorium, 88(5-6), 323-363.

Johnson, H. B. (1975). Plant pubescence: an ecological perspective. The Botanical Review, 41(3), 233-258.

Kecskeméti, T. (1998). Magyarország epikontinentális eocén képződményeinek rétegtana. (Stratigraphy of the epicontinental Eocene formations of Hungary). In I. Bérczi \& A. Jámbor (Eds.) Magyarország Geológiai Képzödményeinek Rétegtana (Stratigraphy of the geological formations of Hungary), MOL and MÁFI, 403-418.

Kedves, M. (1960). Études Palynologiques dans le Bassin de Dorog, I. Pollen et Spores, 2(1), 89-118.

Kedves, M. (1961). Zur palynologischen Kenntnis des unteren Eozäns von Halimba. Acta Biologica, 7(3-4), 25-41.

Kedves, M. (1962a). Études palynologiques de quelques échantillons du bassin de Tatabánya. Pollen et Spores, 4(1), 155-168.

Kedves, M. (1962b). Palynologic investigations on the freshwater limestone layer of Lábatlan and an attempt to divide the Hungarian Lower Eocene floras on palynologic basis. Acta Biologica, 8(1-4), 63-69.

Kedves, M. (1963a). Stratigraphie Palynologique des Couches Éocènes de Hongrie. Pollen et Spores, 5(1), 149-159.

Kedves, M. (1963b). Contribution à la flore Éocène inférieure de la Hongrie sur la base des examens palynologiques des couches houillères du puits III d'Oroszlány et du puits XV/B de Tatabánya. Acta Botanica Academiae Scientiarum Hungaricae, 9(1-2), 31-66.

Kedves, M. (1966a). Palynológiai adatok a solymári eocén kori barnakőszenes rétegekböl. (Palynological data from the Eocene brown coal deposits of Solymár). Annual Report of the Hungarian Geological Institute of, 1964, 339-347.

Kedves, M. (1966b). Contributions sporo-polliniques à la connaissance Paléobotanique des couches fossilifères de la marnière de
Tatabánya. Acta Botanica Academiae Scientiarum Hungaricae, $12,55-88$.

Kedves, M., \& Kolosváry, G. (1966). Eozän-Korallen und faziesökologisch-biostratigraphisch bemerkenswerte Sporomorphen aus dem Bakony-Gebirge betrachtet. Acta Biologica, 12(1-2), 49-53.

Klucking, E. P. (1987). Leaf venation patterns: volume 2. Lauraceae. Berlin: J. Cramer. pp. 216

Knobloch, E., \& Kvaček, Z. (1976). Miozäne Blätterfloren vom Westrand der Böhmischen Masse. Rozpravy Českého Geologického Ústavu, 42, 1-131.

Knobloch, E., \& Kvaček, Z. (1996). Miozäne Floren der südböhmischen Becken. Sbornik Geologickỳch Věd Paleontologie, 33, 39-77.

Knobloch, E., Konzalová, M., \& Kvaček, Z. (1996). Die obereozäne Flora der Staré Sedlo-Schichtenfolge in Böhmen (Mitteleuropa). Rozpravy Českého Geologického Ústavu, 49, 1-260.

Kovács, É. (1957a). Tropischer Farn aus dem Eozän in Ungarn. Annales Universitatis Scientiarum Budapestinensis de Rolando Eötvös nominatae Sectio Biologica, 1, 185-187.

Kovács, É. (1957b). Dracontomelon minimum Reid et Chandler. Bulletin of the Hungarian Society, 87(2), 215-217.

Kovács, É. (1959). Note sur la Flore Éocène de Lábatlan (Transdanubie Nord). Annales Universitatis Scientiarum Budapestinensis de Rolando Eötvös nominatae Sectio Biologica, 2, 135-140.

Kovács, É. (1961). Középső-eocén flóra Lábatlanról. (Mitteleozäne Flora aus der Umbegung von Lábatlan). Annual report of the Hungarian Geological Institute of 1957 and 1958, 473-495.

Kovács, É. (1968). Études préliminaires sur la flore Éocène de Tatabánya (Hongrie occidentale). Annales Universitatis Scientiarum Budapestinensis de Rolando Eötvös Nominatae / Sectio biologica, 9-10, 231-240.

Kovar-Eder, J., Meller, B., \& Zetter, R. (1998). Comparative investigations on the basal fossiliferous layers at the opencast mine Oberdorf (Köflach-Voitsberg lignite deposit, Styria, Austria; early Miocene). Review of Palaeobotany and Palynology, 101, 125-145.

Kvaček, Z. (1971). Fossil Lauraceae in the stratigraphy of the NorthBohemian Tertiary. Sbornik Geologickỳch Věd Paleontologie, 13, 47-86.

Kvaček, Z. (2002). A new Tertiary Ceratozamia (Zamiaceae, Cycadopsida) from the European Oligocene. Flora, 197, 303-316.

Kvaček, Z. (2004). Revisions to the Early Oligocene flora of Flörsheim (Mainz Basin, Germany) based on epidermal anatomy. Senckenbergiana lethaea, 84(1/2), 1-73.

Kvaček, Z., \& Bůžek, Č. (1966). Einige interessante Lauraceen und Symplocaceen des Nordböhmischen Tertiärs. Věstník Ústředního Ústavu Geologického, 41, 291-294.

Kvaček, Z., \& Walther, H. (1989). Revision der mitteleuropäischen tertiären Fagaceen nach blattepidermalen Charakteristiken. III. Teil Dryophyllum Debey ex Saporta und Eotrigonobalanus Walther et Kvaček gen. nov. Feddes Repertorium, 100, 575-601.

Kvaček, Z., \& Hably, L. (1998). New plant elements in the Tard Clay Formation from Eger-Kiseged. Acta Palaeobotanica, 38(1), 5-23.

Kvaček, Z., \& Wilde, V. (2010). Foliage and seeds of malvalean plants from the Eocene of Europe. Bulletin of Geosciences, 85(1), 163 182.

Kvaček, Z., \& Teodoridis, V. (2011). The late Eocene flora of Kučlín near Bílina in North Bohemia revisited. Acta Musei Nationalis Pragae, Series B-Historia Naturalis, 67(3-4), 83-144.

Mai, D. H. (1963). Beiträge zur Kenntnis der Tertiärflora von Seifhennersdorf (Sachsen). Jahrbuch des Staatlichen Museums für Mineralogie und Geologie zu Dresden, 1963, 39-114.

Mai, D. H., \& Walther, H. (1978). Die Floren der Haselbacher Serie. Abhandlungen des Staatlichen Museums für Mineralogie und Geologie Dresden, 28, 1-200.

Mai, D. H., \& Walther, H. (1985). Die obereozänen Floren des Weisselster-Beckens und seiner Randgebiete. Abhandlungen des 
Staatlichen Museums für Mineralogie und Geologie Dresden, 33, 1260.

Manchester, S. R. (1994). Fruits and seeds of the middle Eocene nut beds Flora, Clarno formation, Oregon. Palaeontographica Americana, $58,1-205$.

Manchester, S. R., \& O'Leary, E. L. (2010). Phylogenetic distribution and identification of fin-winged fruits. The Botanical Review, 76(1), 1-82.

Meller, B., Kovar-Eder, J., \& Zetter, R. (1999). Lower Miocene diaspore-, leaf-, and palynomorph-assemblages from the base of the lignitebearing sequence in the opencast mine Oberdorf N Voitsberg (Styria, Austna) as indication of a "Younger Mastixioid" vegetation. Palaeontographica B, 252(5-6), 123-179.

Mihajlovič, D., \& Ljubotenski, T. (1994). Upper Eocene flora of Ovče Polje, Macedonia. Geologica Carpathica, 45(4), 203-210.

Mosbrugger, V., Utescher, T., \& Dilcher, D. L. (2005). Cenozoic continental climatic evolution of Central Europe. Proceedings of the National Academy of Sciences, 102(42), 14964-14969.

Palamarev, E., \& Petkova, A. (1975). Novi danni za paleocenskata flora na Bulgaria. (Neue Daten über die Paläogene Flora Bulgariens). Bulgarian Academy of Sciences, In Honour of Acad. Daki Jordanov, Sofia, 203-236.

Pálfalvy, I. (1965). Nipa-maradványok a budai felsőeocénből. (NipaReste aus dem Obereozän von Buda). Annual Report of the Hungarian Geological Institute of, 1963, 117-120.

Pálfalvy, I. (1966a). Mangrovepáfrány a Solymári-medencéből. (Ein Mangrovefarn aus dem Becken von Solymár Buda- Pilis Gebirge). Annual Report of the Hungarian Geological Institute of, 1964, 349353.

Pálfalvy, I. (1966b). Stenochlaena maradvány a tatabányai eocénből. (Ein Rest von Stenochlaena aus dem Eozän von Tatabánya). Annual Report of the Hungarian Geological Institute of 1964, 355-359.

Peters, I. (1963). Die Flora der Oberpfälzer Braunkohlen und ihre ökologische und stratigraphische Bedeutung. Palaeontographica Abteilung B, 112, 1-50.

Petrescu, I., Margarit, G., \& Margarit, M. (1976). Flora eocena de la Girbu-Cluj. Dări de Seamă ale ședințelor Ministerul Geolofiei Insitutul de Geologieși Geofizică 3. Paleontologie, 62, 195-228.

Rásky, K. (1943). Die Oligozäne Flora des Kisceller Tons in der Umgebung von Budapest. Bulletin of the Hungarian Geological Society, 73, 503-536.

Rásky, K. (1948). Nipadites burtini Brong. termése Dudarról. (fruit of Nipadites burtini Brong. from Dudar). Bulletin of the Hungarian Society, 78, 130-134.

Rásky, K. (1956a). Fosszilis növények a Martinovics-hegyi (Budapest) felsőeocénból. (Fossil plants from the upper Eocene of the Mount
Martinovics, Budapest). Bulletin of the Hungarian Geological Society, 86, 295-298.

Rásky, K. (1956b). Fosszilis növénymaradványok a dunántúli alsóeocénben. (Fossil plant remains from the lower Eocene of Transdanubia Hungary). Bulletin of the Hungarian Geological Society, 86, 291-294.

Raz, L. (2017). A review of the fossil record for Dioscoreaceae. Botanical Journal of the Linnean Society, 183(4), 495-508.

Roth-Nebelsick, A., Utescher, T., Mosbrugger, V., Diester-Haass, L., \& Walther, H. (2004). Changes in atmospheric CO 2 concentrations and climate from the late Eocene to early Miocene: palaeobotanical reconstruction based on fossil floras from Saxony, Germany. Palaeogeography, Palaeoclimatology, Palaeoecology, 205(1), 43-67.

Rüffle, L. (1976). Myricaceae, Leguminosae, Icacinaceae, Sterculiaceae, Nymphaeaceae, Monocotyledones, Coniferae. Eozäne Floren des Geiseltales. Abhandlungen des Zentralen Geologischen Instituts, Paläontologische Abhandlungen, 26, 337-438.

Rüffle, L., \& Jähnichen, H. (1976). Die Myrtaceen im Geiseltal und einigen anderen Fundstellen des Eozän. Eozäne Floren des Geiseltales Abhandlungen des Zentralen Geologischen Instituts, Paläontologische Abhandlungen, 26, 307-336.

Rüffle, L., Müller-Stoll, W. R., \& Litke, R. (1976). Weitere Ranales, Fagaceae, Loranthaceae, Apocynaceae. Eozäne Floren des Geiseltales. Abhandlungen des Zentralen Geologischen Instituts, Paläontologische Abhandlungen, 26, 199-282.

Schafarzik, F., \& Vendl, A. (1929). Geológiai kirándulások Budapest környékén. (A geological fieldtrip in the environs of Budapest) ( $\mathrm{p}$. 341). Budapest: Stádium.

Tuzson, J. (1913). Adatok Magyarország fosszilis flórájához III. (Additamenta ad Floram Fossilem Hungariae III.). A Magyar Kir. Földtani Intézet Évkönyve (The Annals of the Royal Hungarian Geological Survey), 21(8), 207-233.

Unger, F. (1847). Chloris protogaea. Leipzig. pp. 149

Weyland, H. (1948). Beiträge zur Kenntnis der Rheinischen Tertiärflora. VII. Fünfte Ergänzungen und Berichtigungen zur Flora der Blätterkohle und des Polierschiefers von Rott im Siebengebirge. Palaeontographica Abteilung B, 88(4-6), 113-188.

Wilde, V. (1989). Untersuchungen zur Systematik der Blattreste aus dem Mitteleozan der Grube Messel bei Darmstadt (Hessen, Bundesrepublik Deutschland). Courier Forschungsinstitut Senckenberg, 115, 1-213.

Publisher's note Springer Nature remains neutral with regard to jurisdictional claims in published maps and institutional affiliations. 